\title{
Multimodal Communication in An EARly Childhood Bilingual Education Setting: A Social Semiotic Interaction ANALYSIS
}

\author{
COMUNICACIÓN MULTIMODAL EN UN ENTORNO DE EDUCACIÓN INICIAL BILINGÜE: \\ UN ANÁLISIS SEMIÓTICO-SOCIAL DE LA INTERACCIÓN \\ COMMUNICATION MULTIMODALE DANS UN ENVIRONNEMENT D'ÉDUCATION INITIALE \\ BILINGUE : UNE ANALYSE SÉMIOTIQUE SOCIALE DE L'INTERACTION
}

COMUNiCAÇÃo MULTIMODAL EM UM AMBIENTE DE EDUCAÇÃo INICIAL BILÍNGUE: UMA ANÁLISE SEMIÓTICO-SOCIAL DA INTERAÇÃo

\author{
Wilder Yesid Escobar-Alméciga \\ Director, Licenciatura en Bilingüismo, \\ Facultad de Educación, Universidad \\ El Bosque, Bogotá, Colombia. \\ escobarwilder@unbosque.edu.co \\ https://orcid. \\ org/0000-0002-5082-6236 \\ Janina Brutt-Griffler \\ Associate Dean of International \\ Education and Language Programs \\ Director, Center for Comparative \\ and Global Studies in Education, \\ University at Buffalo, Buffalo, NY, USA \\ bruttg@buffalo.edu \\ https://orcid. \\ org/0000-0001-7250-5444
}

\begin{abstract}
Bilingual learners often integrate semiotic resources and communicative modes across the languages they speak. Unfortunately, current approaches to researching such a phenomenon assign pragmatic functions to individual discourse moves at best or to isolated utterances at worst. Thus, using a social semiotic multimodal interaction analysis, this study examined actions in interactions of a group of six transnational students participating in a second-grade literacy circle at a school in western New York, USA. The purpose of this was to account for the complex reciprocities among their multimodal ways of communicating, their learning climate, and ultimately their learning as mediated and evidenced in their integrated multimodal communicative action. Data included four audio recordings of four literacy circle reading activities that took place during a four-day period. Findings suggest that, first, learning results from communication. Second, learning can only be evidenced through communication in interaction. Finally, communication is always multimodal and emergent while, at the same time, culturally governed. This presents direct implications for instruction and learning regarding the social conditions afforded to students to access their full repertoire of semiotic resources and modes to participate and act on their own behalf and in pursuit of their learning.
\end{abstract}

Keywords: bilingual education; dual-language instruction; early childhood education; literacy; multimodal communication; social semiotics.

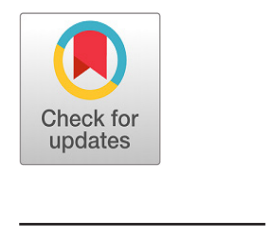

Received: 2021-03-05 / Accepted: 2021-08-05 / Published: 2022-02-11

https://doi.org/10.17533/udea.ikala.v27n1a05

Editor: Doris Correa, Universidad de Antioquia, Medellín, Colombia

Some rights reserved, Universidad de Antioquia, 2022. This is an open access article distributed under the terms of the Creative Commons License BY-NC-SA 4.0 International. 


\section{RESUMEN}

Los aprendices bilingües muchas veces integran recursos semióticos y comunicativos entre las lenguas que hablan. Desafortunadamente, las actuales investigaciones sobre dicho fenómeno asignan funciones pragmáticas a formas de discurso individual en el mejor de los casos o a expresiones aisladas en el peor de ellos. Por ende, utilizando modelos de la interacción multimodal sociosemiótica, este estudio analizó acciones en las interacciones de un grupo de seis estudiantes transnacionales que participaron en un círculo de literacidad de segundo grado en una escuela al oeste de Nueva York, Estados Unidos. El propósito era explicar las complejas reciprocidades entre sus formas de comunicación multimodal, su ambiente de aprendizaje y, en última instancia, su aprendizaje como algo mediado y evidenciado en su acción comunicativa multimodal integrada. Los datos incluyeron cuatro grabaciones de audio obtenidos en cuatro círculos de lectura llevados a cabo en cuatro días. Los hallazgos indican que, en primer lugar, el aprendizaje se deriva de la comunicación. En segundo lugar, el aprendizaje solo puede evidenciarse mediante la comunicación en la interacción. Finalmente, la comunicación es siempre multimodal y emergente, pero, al mismo tiempo, está determinada por la cultura. Esto plantea implicaciones directas para la enseñanza y el aprendizaje en relación con las condiciones sociales al alcance de los estudiantes para acceder a su repertorio pleno de recursos semióticos y modos de participación y acción en nombre propio y en pos de su aprendizaje.

Palabras clave: educación bilingüe; enseñanza en dos idiomas; educación inicial; literacidad; comunicación multimodal; sociosemiótica.

\section{RÉSUMÉ}

Les apprenants bilingues intègrent souvent des ressources sémiotiques et communicatives entre les langues qu'ils parlent. Malheureusement, les recherches actuelles sur ce phénomène attribuent des fonctions pragmatiques à des formes individuelles de discours dans le meilleur des cas ou à des expressions isolées dans le pire des cas. Par conséquent, en utilisant des modèles d'interaction sociosémiotique multimodale, cette étude a analysé les actions dans les interactions d'un groupe de six étudiants transnationaux qui ont participé à un cercle d'alphabétisation de deuxième année dans une école de l'ouest de New York, aux États-Unis. Le but était d'expliquer les réciprocités complexes entre leurs formes de communication multimodale, leur environnement d'apprentissage et, finalement, leur apprentissage tel qu'il est médiatisé et mis en évidence dans leur action communicative multimodale intégrée. Les données comprenaient quatre enregistrements audio obtenus dans quatre cercles de lecture réalisés sur quatre jours. Les résultats indiquent que, tout d'abord, l'apprentissage découle de la communication. Deuxièmement, cet apprentissage ne peut être mis en évidence que par la communication dans l'interaction. Enfin, la communication est toujours multimodale et émergente, mais, en même temps, elle est déterminée par la culture. Cela soulève des implications directes pour l'enseignement et l'apprentissage en ce qui concerne les conditions sociales offertes aux étudiants pour accéder à leur répertoire complet de ressources sémiotiques et de modes de participation et d'action pour leur propre compte et dans la poursuite de leur apprentissage.

Mots-clefs : éducation bilingue; enseignement en deux langues; formation initiale ; alphabétisation; communication multimodale; socio-sémiotique. 


\section{RESUMO}

Os aprendizes bilíngues geralmente integram recursos semióticos e comunicativos entre os idiomas que falam. Infelizmente, as pesquisas atuais sobre esse fenômeno atribuem funções pragmáticas a formas individuais de discurso no melhor dos casos ou a expressões isoladas no pior deles. Portanto, utilizando modelos de interação multimodal sociossemiótica, este estudo analisou ações nas interações de um grupo de seis estudantes transnacionais que participaram de um círculo de alfabetização de segunda série em uma escola no oeste de Nova York, Estados Unidos. O objetivo foi explicar as complexas reciprocidades entre suas formas de comunicação multimodal, seu ambiente de aprendizagem e, em última análise, sua aprendizagem mediada e evidenciada em sua ação comunicativa multimodal integrada. Os dados incluíram quatro gravações de áudio obtidas em quatro rodas de leitura realizadas em quatro dias. Os achados indicam que, antes de tudo, a aprendizagem deriva da comunicação. Segundo, que a aprendizagem só pode ser evidenciada por meio da comunicação em interação. Por fim, a comunicação é sempre multimodal e emergente, mas, ao mesmo tempo, determinada pela cultura. Isso traz implicações diretas para o ensino e a aprendizagem em relação às condições sociais disponíveis para os alunos acessarem todo o seu repertório de recursos semióticos e modos de participação e ação em nome próprio e na busca de sua aprendizagem.

Palavras chave: educação bilíngue; ensino em duas línguas; educação inicial; alfabetização; comunicação multimodal; sócio-semiótica. 


\section{Introduction}

Schools in the U.S. resemble the diversity of their broader national context and are left with the charge of educating students from different sociocultural backgrounds (Castles et al., 2013; Flores, 2010) and to determine the extent to which the students' linguistic and sociocultural heritage has a place in the education process (Goldenberg \& Coleman, 2010).

Current approaches to researching the instances in which such sociocultural aspects surface the school contexts focus heavily on examining isolated instances of the use of the students' L1 (García \& Nava, 2012; Jaffe, 2007; Macswan, 2013) or on the implementation of pedagogical approaches that treat languages separately creating learning environments where the coexistence of the two languages is not possible (García-Mateus \& Palmer, 2017). Such views deviate greatly from a social semiotic perspective in that they (1) do not explain learning on the basis of communication and (2) that they fail to recognize that the languages a person speaks and their sociocultural, historical, and semiotic resources and modes are interconnected as one integrated repertoire for communicative action (Cenoz \& Gorter, 2017; Kress, 2010, 2011; Norris, 2004, 2014). Thus, there still exists a pressing need for a social-semiotic multimodal communication-based approach where the use of the students' L1 and any other semiotic resource or communicative mode can be interpreted in relation to each other and in light of the communicative action being pursued and the social climate being promoted (Fairclough, 2011; Norris, 2014).

As such, we relied on multimodal interactional analysis (MIA; Norris, 2004) to investigate communicative episodes of six second-grade Puerto Rican-US transnational students and their teacher during reading tasks to inquire into the way in which the students' L1 (inter)acted with other semiotic resources for meaning-making in communication as they grappled with text-related questions in their literacy circles. Two questions guided this study: (1) How do students configure their L1 with other semiotic resources and modes for meaning-making in communicative action? and (2) what implications may the integration of the students' L1 with other semiotic resources have for instruction?

\section{Theoretical Framework}

The intricate, complex and reciprocal relationship that communication, teaching, and learning hold with each other in a bilingual school environment can be better explained in light of social semiotics. Hence, this section delves into the concept of social semiotics to, subsequently, discuss bilingual education approaches.

\section{Social Semiotics in Education}

Social semiotics is concerned with the ways in which meaning-making is or fails to be accomplished in environments of communication (Fairclough, 2011; Kress, 2011). It offers a view where meaning-making in communication is complex, multimodal, and socio-culturally governed. That is, communication is comprised of far more elements than just the spoken or written linguistic codes. Rather, communication encompasses countless resources and modes with which semiotic systems are created, configured, and deployed (Franks \& Jewitt, 2001; Goldin-Meadow, 2000; Norris, 2014; Roth, 2001), including the bilingual child's two languages. In that sense, semiotic resources are the materials, elements, actions available to create meaning, while communicative modes are the ways in which such resources are configured, organized, and deployed to create, shape, and reshape meaning in interaction. Consistently, meaning here is unevenly distributed among different resources and modes - mode complexity, intensity and density (Norris, 2004). While some episodes may exhibit numerous modes and resources (a high-level density), others may display fewer modes (a low-level density). Consistently, the importance that a particular 
mode has in unlocking meaning as opposed to all other modes in the communicative episode is referred to as mode intensity.

In Kress' (2011) terms, the sign is the sociocultural work of the agent to make, interpret, negotiate, and sometimes, struggle over meaning in interaction. It results from the person's representation system which is formed and transformed by their sociocultural surroundings and background. In this sense, Kress' sign is an act(ion) - a word, a gesture, body postures-which, through time, is populated with sociocultural properties that form and transform its meaning into something that could be socially recognized, reconciled, or negotiated in interaction and that has the potential to change and be changed by the semiotic work of others (Kress, 2010, 2011).

Thus, social semiotics in education represents a comprehensive perspective that, first, acknowledges that learning comes as a result of multimodal communication, second, values different ways of knowing, and third, accepts multimodal ways of accounting for such types of knowledge and ways of knowing (Kress, 2010, 2011). In doing so, it establishes a clear, strong, and direct association between multimodal communication and learning. Learning, within this framework, "happens in complex social environments; always in interaction with 'the world', often in interaction with (members of) distinct social groups and their distinct and related interests" (Kress, 2011, p. 214).

In this perspective, the sign makers are active agents in communication acting collectively in pursuit of learning. Their histories, cultural knowledge, experiences, idiosyncrasies, personal/social relations, perspectives of the world, identities, interests, etc., are always brought to bear in the construction of knowledge within the similarities and across the differences of the interactants. Hence, the sign can be taken as evidence of the learner's sociocultural knowledge, their engagement with what is being addressed, their response to other signs, their epistemological commitment to the subject at hand, and the formation and transformation of their identities through their participation (Franks \& Jewitt, 2001; Kress, 2010, 2011).

Consistently, the extent to which participation is allowed and supported determines the degree to which social cohesion and communication are achieved. Reciprocally, such degree of social cohesion and communication regulates access to and distribution of semiotic, cultural, social, affective, and economic resources needed for full participation and, hence, for learning (Kress, 2010). In his words, "members of communities [should] have access to the semiotic and other cultural resources essential to act in their social world on their own behalf and for their benefit" (Kress, 2010, p. 18).

As such, analyzing multimodal interaction in bilingual education from a social semiotic perspective offers means of unveiling the extent to which (semiotic, cultural, affective, cognitive, etc.) resources work together in communication and learning and are made evenly or unevenly available to students for a fair or unfair share of participation in the common goal of accessing and constructing knowledge in the classroom.

\section{Bilingual Education Approaches}

The literature advocates for bilingual approaches to children's education and to their home upbringing with a wide-ranging scope of arguments.

At a cognitive level, Ben-Zeev (1977) explained the mental strategies that bilingual children use in communication in order to cope with the broader range of communicative possibilities that drawing on two linguistic resources pose. Not only do such strategies involve extremely complex mental processes like intensified scanning of language input and careful self-monitoring of their output, but they are also highly demanding in regards to the time afforded to the speakers to perform such processes. As a result of mental activities of this sort, cognitive skills are enhanced and cognitive development is expedited (Graf Estes \& Hay, 2015; 
Poepsel \& Weiss, 2016). In a similar way, Graf Estes and Hay (2015) argued that early bilingualism fosters extended flexibility in early lexical development. Bilingual children need to identify and differentiate the boundaries of their two phonological and morphological systems as well as comprehend the underlying principles that determine the adequate use of each system in communication.

In terms of the reciprocal relationship that exists between identity and learning, for instance, García-Mateus and Palmer's (2017) analysis of the classroom discourse practices of a group of students and their teacher found that the teacher had an approach to instruction where the students' languages were fluidly and dynamically used. This increased student-metalinguistic awareness, offered fair opportunities for students to take part in class activities, fostered identity construction processes, and empowered minoritized students to pursue their learning interests.

In reference to the role that families play in the emotional, cognitive, and social development of children and in regard to the disproportionate social status that immigrant languages have in relation to English in the U.S., Leung and Uchikoshi (2012) studied the ideologies, attitudes, and practices that parents of Cantonese and English early bilinguals had concerning their children's acquisition and use of their heritage language and the effects of such attitudes, practices, and ideologies on their academic achievement. Parents were asked about the reasons for enrolling their kids in bilingual programs and whether they believed that their children should maintain their Cantonese language. The parents' responses unveiled (1) a concern for maintaining the heritage language, (2) an appreciation for the opportunity that these Cantonese/English bilingual schools afforded them to get involved as they did not speak English, and (3) their awareness about what their children's enhanced linguistic capital would represent for their future. The findings of this study showed that, on the one hand, these Cantonese-English bilinguals' communicative and academic performance was significantly improved by the bilingual school environment available to them, and on the other, the students' motivation and high achieving outcomes in the acquisition of Cantonese came as a direct result of their parents' positive attitudes and ideologies about their heritage language.

From an opposing view, Flores and García (2017) explored the negative effect that certain approaches to bilingual education are bringing about. They found that, overtime, bilingual education programs shifted their focus from attending to the learning needs of culturally diverse children from minoritized communities to serving marketing objectives and catering primarily to middle-class Caucasian families. While acknowledging the progress that this educational matter has made over the years, they attested to the need for bilingual education approaches that empower minoritized students and provide them with equitable opportunities to learn like translanguaging. This concept promotes the integrated, strategic, and designed use of more than one language for classroom instruction. While translanguaging is not grounded in social semiotics, it does begin to acknowledge that the two languages that a bilingual child speaks represents one linguistic repertoire for communication. It also seeks to foster the development of bilingual identities and to empower culturally diverse students to use their two languages to act on their own behalf and in pursuit of their benefit (Ascenzi-Moreno, 2018; Cenoz \& Gorter, 2017; Collins, 2014; García-Mateus \& Palmer, 2017; Hamman, 2018; MacSwan, 2017, 2020; Rodríguez, 2015).

The study at hand, however, has the ambitious intention of taking the premises under which translanguaging operates one step beyond. It seeks to complement the idea that bilingual students have their two languages integrated as one communicative repertoire by arguing that in addition to speech, such a communicative repertoire is also 
composed of other semiotic resources and communicative modes like gestures, gaze, proxemics, performance, and so on, which are historically and socio-culturally governed. As such, these semiotic resources and communicative moods need to be assessed in light of one another and in their interplay in multimodal communication rather than in isolated instantiations of a communicative phenomenon. In other words, bilingual pedagogy can be well served by studies that frame learning as an effect of multimodal communication to inquire into the ways in which such communication is configured in instruction and the extent to which these configurations increase or limit learning possibilities for bilingual students. Such studies would inform instructional designs that welcome, value, and include the students' linguistic, sociocultural, and semiotic resources in class activity to ensure ample opportunities to fully participate in school life.

\section{Method}

Within the area of social semiotics, Norris (2004) proposes an analytical framework that addresses communication from a multimodal perspective. She delineates a methodology which guides inquiries into the ways in which people create, form, transform, and use their social, semiotic, cultural, emotional, and cognitive resources to (inter)act, (inter)represent, and (inter)be in social contexts and to unveil how such arrangements grant or deny access to, for instance, social participation. As such, this is an MIA (Kress, 2010, 2011; Norris, 2004) which reports its findings on the basis of communicative episodes (Aukerman et al., 2017).

In this framework, Norris (2004) takes the action as an interactional meaning unit and, hence, the unit of analysis to investigate the way in which semiotic resources and modes are configured and deployed in communicative action. In this sense, actions can be (1) lower-level-the smallest interactional unit of meaning or (2) higher-level-bracketed by an opening and closing and composed of lower-level and sometimes other higher-level actions. Actions, in this model, are what the students and teacher do in pursuit of communicative aims using the semiotic resources and modes that they have at their disposal. This model offers two main categorical themes: mode density and mode intensity to explain mode complexity (how semiotic resources like words, movement, color, and silences are configured into communicative action and deployed through modes like speech, gestures, and layout for meaning-making in the learning process). As such, mode density refers to the amount of modes involved in communicative action, and the framework seeks to graphically delineate the intricate interactions among them. Similarly, mode intensity refers to the varying degrees to which particular resources or modes play greater or lesser roles in meaning-making, and in the framework, it is usually represented with oval-shaped graphs which through their overlapping show relations and through size illustrate the degree of importance in a particular communicative act. Finally, episodes are those activities that take place within speech situations and are governed by the collective social norms shared among the participants. It can consist of one or more actions, and it is contained within a culturally organized and thematic sequenced of actions bounded by its communicative interrelations.

\section{Context, Participants and Data Collection}

In western New York, APRENDER is a school with 95\% of Spanish speaking children of Latino ethnicity, mainly transnationals between Puerto Rico and The United States of America. That is, students are mainly from Puerto Rico; however, their lives happen fluidly between these two countries which have close political ties. The students have different levels of proficiency in both English and Spanish and come from diverse socioeconomic backgrounds.

This institution is of particular value for understanding the role that $\mathrm{L} 1$ plays in communication and learning, as this is a bilingual program whose 
curriculum is taught in both English and Spanish (a dual language immersion program) and whose students, holistically speaking, need to have a functional command of the two languages in order to fully participate in the contexts between which they regularly move.

In APRENDER, the second-grade group resembles the characteristics of the broader institutional context as shown in Table 1. The teacher was a Caucasian woman formed as a bilingual educator with vast experience in the United States as well as abroad (Spain). For the literacy-circles, the students were divided into three groups based on the student's assumed reading level. The students' reading level and placement in groups was largely influenced by factors like the length of time that the student had lived in the United States, proficiency in the English language, interrupted school time and so forth. For this study, it was important that the students participating had a fairly good command of English and reading so that the explanation for phenomena like the use of additional modes of communication or the use of their L1 in their interactions would not merely be about their lack of proficiency in English.

Additionally, in trying to understand collectively constructed norms and patterns of interaction, it was also essential to examine students who had attended the school for a significant period of time where the classroom culture and their collectively constructed communal conventions could be considered within the analysis of such interactions. As such, the green group, the focus of the communicative episodes under discussion here, was composed of six students. These students had attended APRENDER for at least an entire school year, and the school had placed them at their grade level in terms of proficiency in English and reading.

Recordings were collected twice a week for two class periods of 50 minutes each during an entire semester. The focal data for this article, however,

Table 1 Demographics and Linguistic Characteristics

\begin{tabular}{|c|c|c|c|c|c|c|}
\hline & $\mathbf{N}$ & Percent & Mean & SD & Min & Max \\
\hline \multicolumn{7}{|l|}{ Gender } \\
\hline Girls & 10 & $50 \%$ & & & & \\
\hline Boys & 10 & $50 \%$ & & & & \\
\hline \multicolumn{7}{|l|}{ Birth Place } \\
\hline Puerto Rico & 14 & $70 \%$ & & & & \\
\hline US & 6 & $30 \%$ & & & & \\
\hline Free/reduced lunch & 20 & $100 \%$ & & & & \\
\hline \multicolumn{7}{|l|}{ Special education } \\
\hline Yes & 4 & $21 \%$ & & & & \\
\hline No & 16 & $79 \%$ & & & & \\
\hline
\end{tabular}

\begin{tabular}{lcccccc}
\hline $\begin{array}{l}\text { ESL Status (School } \\
\text { Record) }\end{array}$ & & & & & & \\
ESL & 18 & $90 \%$ & & & & \\
Non- ESL & 2 & $10 \%$ & & & & \\
\hline Age (months) & 20 & & 93.95 & 9.31 & 84 & 112 \\
\hline Time in the US (months) & 20 & & 48.21 & 34.86 & 1 & 112 \\
\hline Time in school (months) & 20 & & 23.89 & 14.95 & 1 & 45 \\
\hline Time in ESL program (years) & 20 & & 3.37 & 1.16 & 1 & 5 \\
\hline
\end{tabular}


Table 2 Five-Item Criterion

\begin{tabular}{ll}
\hline Item & \multicolumn{1}{c}{ Criterion } \\
\hline 1 & In the episode, a question about a word or a concept related to the text was asked. \\
2 & Students' Ll assisted communication in the process of answering the question. \\
3 & Additional semiotic resources and/or modes were integrated for meaning making in the episode \\
4 & The answering process exhibited collective effort (two or more students grappled with the question or concept at hand) \\
5 & The use of students' LI was validated and conducive to a resolution in the meaning making process. \\
\hline
\end{tabular}

Table 3 Mode-Related Codes and Explanation

\begin{tabular}{|c|c|c|}
\hline Code & Explanation & Analysis \\
\hline Gestures & Body movements that convey meaning & $\begin{array}{l}\text { Type of action, semiotic resources, semiotic } \\
\text { representations, intended meaning, and communicative } \\
\text { outcome }\end{array}$ \\
\hline Speech & Talk & $\begin{array}{l}\text { Talk, semiotic resources like paralinguistic prosody i.e., } \\
\text { tone of voice, silence, semiotic representations..., and } \\
\text { communicative outcome }\end{array}$ \\
\hline Performance & $\begin{array}{l}\text { The integration of many body movements, } \\
\text { gestures and other modes to represent a } \\
\text { meaningful scene or situation. }\end{array}$ & $\begin{array}{l}\text { Type of action, semiotic resources, semiotic } \\
\text { representations, intended meaning, and communicative } \\
\text { outcome }\end{array}$ \\
\hline
\end{tabular}

is composed of the audio recordings from the literacy events that took place in Lesson 21, which were transcribed following the Jefferson transcription system (Jefferson, 2004). Lesson 21's structure closely resembled the general structure for all the lessons for the literacy circles. Its main theme was Animal Development. This lesson was captured in four audio recordings of four literacy circle reading activities during a four-day period. The length of these literacy circles ranged from 41 to 53 minutes. Lesson 21, the focal data, became of interest for this particular inquiry because of the quality of multimodal interaction that it generated among the students of the green group in the second-grade classroom.

\section{Data Analysis}

This is an MIA which examined the forms and functions that students' communicative action took in communicative episodes as they grappled with text related questions in literacy circles (Aukerman et al., 2017; Norris, 2004). An initial level of analysis identified episodes in which the students' L1 assisted student communication as they read and dealt with concepts. To this end, we employed the following five-item criterion to guide the selection of the focal episodes (see Table 2).

In a subsequent stage, we coded the way the participants used resources and modes in communicative action. Table 3 shows the codes that emerged in this stage, and Table 4 shows a code example.

Finally, we drew connections across codes and episodes to identify patterns and brought them into categorical themes to gain a broader understanding of the way resources and modes interacted and what this could unveil about communicative action and learning. Table 5 shows the categorical themes and Table 6 presents an example.

\section{Findings}

The following three episodes were illustrative of the concept of mode complexity discussed by Norris (2004). Each episode exhibited a multiplicity of 
Table 4 Mode-Related Code and Example

\begin{tabular}{ll}
\hline \multicolumn{1}{c}{ Data } & \multicolumn{1}{c}{ Code } \\
\hline EPS.1.26. Andrea: ((Andrea took her right hand up and Performance & Analysis \\
slightly twisted it palm-up to the right, then her left hand & $\begin{array}{l}\text { Higher-level action. } \\
\text { Andrea uses culturally constructed elements } \\
\text { followed her right which she, then, rested palm-down on top } \\
\text { like the gesture with the hands on her chick to } \\
\text { leaned her head softly onto the right resting her right chick }\end{array}$ \\
on the back of her left hand (the dorsal side of her left hand). \\
Simultaneously, Andrea mimicked the sound of snoring.))
\end{tabular}

Table 5 Categorical Themes and Explanation

\begin{tabular}{|c|c|}
\hline Code & Explanation \\
\hline $\begin{array}{l}\text { - Communicative actions that served to draw } \\
\text { semiotic associations across languages for } \\
\text { meaning negotiation }\end{array}$ & $\begin{array}{l}\text { - Examined the ways actions were configured } \\
\text { and what they indicated about semiotic } \\
\text { associations across languages for meaning } \\
\text { negotiation. }\end{array}$ \\
\hline $\begin{array}{l}\text { - Communicative actions that validated and } \\
\text { supported the students' use of their LI }\end{array}$ & $\begin{array}{l}\text { - Discussed the possibilities that were offered } \\
\text { to students to resort to all their semiotic } \\
\text { resources in interaction. }\end{array}$ \\
\hline $\begin{array}{l}\text { - Communicative actions that formed and } \\
\text { transformed their social environment }\end{array}$ & $\begin{array}{l}\text { - Addressed and described the type and } \\
\text { properties of the social environments that was } \\
\text { being created by the sort of communication } \\
\text { being promoted in the classroom. }\end{array}$ \\
\hline
\end{tabular}

Table 6 Categorical Themes Example

\begin{tabular}{|c|c|}
\hline Data & Code \\
\hline EPS.2. & Communicative actions that served to draw \\
\hline $\begin{array}{l}\text { Mrs. Clair: } 0 \text { k, so } \downarrow \text { their webbed } \uparrow \text { fee:::t... }=\text { what, } \uparrow \text { what are the } \downarrow \text { toes } \uparrow \text { ioined } \\
\text { by } \downarrow \text { there? (4.0) }\end{array}$ & $\begin{array}{l}\text { semiotic associations across languages for } \\
\text { meaning negotiation }\end{array}$ \\
\hline Diego: $>$ The... the $\ldots$ the::: $\ldots<$ la chancl $\uparrow$ eta $\downarrow$ thing! (.) & \\
\hline
\end{tabular}

semiotic resources and communicative modes intricately integrated in communicative action. In each episode, meaning was distinctly distributed across different modes (density), and each episode had a different mode taking on prevalence in meaning-making (intensity).

\section{Modal Complexity: Intensity in Performance}

The first episode, The Brood Patch!, shows the way in which the group deployed collective action integrating a vast array of semiotic resources and modes and the multimodal way in which students took part in interaction in the literacy circles (see Table 7). Contrary to the common assumption that speech is the communicative mode at the core of meaningmaking, in this particular instance, performance, took greater importance in communication.

In the quest to teach brood patch, the book drew a connection to something that was assumed to be culturally-shared knowledge among children of the second group age-a sleeping bag. The teacher, checked to make sure that the association that the book made was understood in Turn 25. Even though Andrea demonstrated that she knew the meaning of the word sleeping by gesturing and making a sound that resembled snoring in Turn 26, the teacher realized that the students did not fully know the concept of this compound word. 
Table 7 Episode 1: The Brood Patch!

\begin{tabular}{|c|c|}
\hline Episode transcription & English translation of $L 1$ instances \\
\hline 1. Mrs. Clair: $\uparrow \ln \_$to (.) & \\
\hline 2. $S S[$ chorus]: $\uparrow \ln \downarrow$ to (.) & \\
\hline 3. Mrs. Clair: $\downarrow A>$ spec $\uparrow$ ial $\downarrow$ place $<$ (.) & \\
\hline 4. SS[chorus]: $\downarrow$ A spec $\uparrow$ ial $\downarrow$ place (.) & \\
\hline 5. Mrs. Clair: $\uparrow$ Ca:::II $\downarrow$ ed (.) & \\
\hline 6. SS[chorus]: $\uparrow(a \cdots:: I \downarrow \downarrow$ ed $()$. & \\
\hline 7. Mrs. Clair: $\downarrow A \uparrow$ brood $\downarrow$ patch (.) & \\
\hline 8. $\quad$ SS [chorus]: $\downarrow A \uparrow$ brood $\downarrow$ patch (.) & \\
\hline 9. Mrs. Clair: $\downarrow$ The $\uparrow \underline{\underline{e \ldots: . g g}(.)}$ & \\
\hline 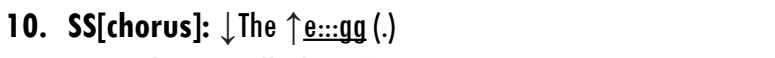 & \\
\hline 11. Mrs. Clair: $\uparrow$ Will $\downarrow$ be::: (.) & \\
\hline 12. SS[chorus]: $\uparrow$ Will $\downarrow$ be::: (.) & \\
\hline 13. Mrs. Clair: $\downarrow$ As $\uparrow s \underline{\text { snug }}$ (.) & \\
\hline 14. SS[chorus]: $\downarrow$ As $\uparrow \underline{s n u g}$ (.) & \\
\hline 15. Mrs. Clair: $\downarrow$ And $\uparrow \underline{w a \ldots \ldots r .} \downarrow \downarrow \mathrm{m}$ (.) & \\
\hline 16. SS[chorus]: $\downarrow$ And $\uparrow \underline{w a: \ldots r} \downarrow \downarrow \mathrm{m}()$. & \\
\hline 17. Mrs. Clair: $\uparrow \underline{T h e:::} \downarrow \downarrow$ re::: (.) & \\
\hline 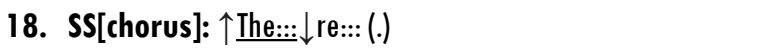 & \\
\hline 19. Mrs. Clair: $\uparrow \underline{A s} \downarrow$ if (.) & \\
\hline 20. SS[chorus]: $\uparrow$ As $\downarrow$ if (.) & \\
\hline 21. Mrs. Clair: $\uparrow$ It $\downarrow$ were::: (.) & \\
\hline 22. SS[chorus]: $\uparrow I t \downarrow$ were::: (.) & \\
\hline 23. Mrs. Clair: $\uparrow \ln \downarrow a>\uparrow$ sleeping $\downarrow$ bag $<$ (.) & \\
\hline 24. SS[chorus]: $\uparrow \ln \downarrow a>\uparrow$ sleeping $\downarrow$ bag $<$ (.) & \\
\hline 25. Mrs. Clair: $\uparrow \underline{\text { Who }} \downarrow$ knows what a $\uparrow$ sleeping $\downarrow$ bag is? (.) & \\
\hline 26. Andrea: $\downarrow$ Like $\uparrow$ THIS gaaugggzzzZZZ ((Andrea took her & \\
\hline right hand up and slightly twisted it palm-up to the right, & \\
\hline then her left hand followed her right which she, then, rested & \\
\hline palm-down on top of her right hand putting her two palms & \\
\hline together. Then, she leaned her head softly onto the right & \\
\hline resting her right chick on the back of her left hand (the dorsal & \\
\hline side of her left hand). Simultaneously, Andrea mimicked the & \\
\hline sound of snoring.)) (.) & \\
\hline 27. Mrs. Clair: Camila Karla, $\uparrow$ what is $\downarrow$ a $\uparrow$ sleeping $\downarrow$ bag? (.) & \\
\hline 28. Camila Karla: $i E n ~ l a \uparrow c a m \downarrow a$, durm $\uparrow$ iendo? (.) & \\
\hline 29. Mrs. Clair: $\downarrow$ Ángel do $\uparrow$ you $\downarrow$ know? (.) & 28. Camila: In bed, sleeping? \\
\hline $\begin{array}{l}\text { 30. Ángel: Es algo muy } \uparrow \text { sua } \underline{a}:: \downarrow \text { ve que es como un } \uparrow \text { círcu } \downarrow \text { lo } \\
\text { que } \uparrow \text { tú } \downarrow \text { te } \uparrow \text { sien } \downarrow \text { tas enc } \uparrow i \downarrow \text { ma (.) }\end{array}$ & \\
\hline 31. Andrea: iNO:::! [es un ...] (.) & 30. Ángel: Something very soft which is round and you sit on it. \\
\hline $\begin{array}{l}\text { 32. Mrs. Clair: [0k], (.) if } \uparrow \text { you } \downarrow \text { go camp } \uparrow \text { ing, you might need } \\
\text { a sleeping bag. }<\downarrow \text { If you } \downarrow \text { go to your } \uparrow \underline{\text { friend's house } \downarrow \text { for a }} \\
\text { sleepo } \downarrow \text { ver }>\text { you might need a } \uparrow \text { sleeping } \downarrow \text { bag (.) }\end{array}$ & 31. Andrea: Nooo! It's a ... \\
\hline 33. (SS: penguins ... unintelligible background talk) (.) & \\
\hline
\end{tabular}

20. SS[chorus]: $\uparrow$ As $\downarrow$ if (.)

21. Mrs. Clair: $\uparrow$ It $\downarrow$ were:::: (.)

22. SS[chorus]: $\uparrow$ It $\downarrow$ were::: (.)

23. Mrs. Clair: $\uparrow \ln \downarrow a>\uparrow$ sleeping $\downarrow$ bag $<$ (.)

24. SS[chorus]: $\uparrow \ln \downarrow a>\uparrow$ sleeping $\downarrow$ bag $<$ (.)

25. Mrs. Clair: $\uparrow \underline{W h o} \downarrow$ knows what a $\uparrow$ sleeping $\downarrow$ bag is? (.) right hand up and slighty twisted it palnep to the right, then her left hand followed her right which she, then, rested palm-down on top of her right hand putting her two palms ogether. Then, she leaned her head softly onto the right resting her right chick on the back of her left hand (the dorsal side of her left hand). Simultaneously, Andrea mimicked the

27. Mrs. Clair: Camila Karla, $\uparrow$ what is $\downarrow a \uparrow$ sleeping $\downarrow$ bag? (.)

28. Camila Karla: $i E n$ la $\uparrow$ cam $\downarrow a$, durm $\uparrow$ iendo? (.)

29. Mrs. Clair: $\downarrow$ Ángel do $\uparrow$ you $\downarrow$ know? (.)

. Ángel: Es algo muy $\uparrow$ sua $:: \downarrow \downarrow$ ve que es como un $\uparrow$ círcu $\downarrow$ lo

. Andrea: $\mathrm{iNO}::: !$ [es un ....] (.)

Mrs. Clair: [0k], (.) if $\uparrow$ you $\downarrow$ go camp $\uparrow$ ing, you might need

31. Andrea: Nooo! It's a .. 
Table 7 Episode 1: The Brood Patch! (Cont.)

\begin{tabular}{|c|c|}
\hline Episode transcription & English translation of $\mathrm{Ll}$ instances \\
\hline $\begin{array}{l}\text { 34. Ángel: i } \uparrow \text { Miss, } \downarrow \text { es as } \uparrow \uparrow \text { ! ((he stood up from his chair. Once he } \\
\text { had Ms. Clair's attention, he lowered his body to the grown and sat } \\
\text { on the floor. Then, he lifted his two legs up into the air. He closed his } \\
\text { wrists as if was holding something in them and stretched his two } \\
\text { arms out in front of him reaching for the tip of his feet. Then, he } \\
\text { slowly pulled his arms toward his body tracing back the side of his } \\
\text { legs with his hands on each side, passing by his waist and continuing } \\
\text { up towards his upper body as if he was covering himself.)) (.) } \\
\text { 35. Mrs. Clair: YE::::S! Look what... Ángel, } \uparrow \text { show } \downarrow \text { them what you } \\
\uparrow \text { do! (2.0) } \\
\text { 36. Ángel: } \uparrow \text { I } \downarrow \text { got on the } \uparrow \text { floor } \downarrow \text { and it } \uparrow \text { keeps } \downarrow \text { you } \uparrow \text { warm (.) } \\
\text { 37. Mrs. Clair: } \uparrow \text { ye:::s, and it keeps you } \uparrow \text { warm (.) } \downarrow \text { it’s } \uparrow l i k e \\
\text { (.) } \downarrow \text { un } \uparrow \text { sac } \downarrow 0=\text { like a sa::: } \uparrow \text { right? (1.0) } \\
\text { 38. Ángel: on } \uparrow T \downarrow V \uparrow \text { they } \downarrow \text { show different } \uparrow \text { animals that... (.) } \\
\text { 39. Mrs. Clair: } \uparrow \text { Yeah, } \downarrow \text { so, that's } \uparrow \text { sleeping } \downarrow \text { bag! }\end{array}$ & $\begin{array}{l}\text { 34. Ángel: Miss, is like this! } \\
\text { 37. Mrs. Clair: yes, and it keeps you warm... it's like... a } \\
\text { sac ... like a sac, right? }\end{array}$ \\
\hline
\end{tabular}

As sleeping bag was a more commonly used expression than brood patch, the teacher's efforts shifted directions to give priority to the teaching of sleeping bag. This higher-level action is bracketed by an opening (Mrs. Clair's question "Who knows what a sleeping bag is?" in Turn 25) and a closing (Mrs. Clair's validation and ratification of the question's resolution “个Yeah, $\downarrow$ so, that's $\uparrow$ sleeping $\downarrow$ bag!" in Turn 39). It is also made up of a chain of lowerlevel actions. In Turn 30, for instance, Ángel used the description of a cushion to define sleeping bag and Andrea immediately refuted Ángel's definition. Subsequently, Mrs. Clair provided examples of where a sleeping bag maybe used to lead the students to a resolution of the question (Turn 32).

In addition to being composed of a sequence of lower-level actions, this higher-level action (the conversation about the meaning of sleeping bag) also contained other higher-level actions embedded within. For instance, in Turn 26, Andrea provided an explanation which did not only contain a sequence of lower-level actions, but that it also integrated a multiplicity of modes. As a response to Mrs. Clair's question, Andrea opened her higher-level action (her grappling with Mrs. Clair's question) with the announcement that her answer was going to be demonstrated by saying "Like this" in Turn 26. Then, she gestured and performed going to sleep and made a sound that resembled snoring as a part of her performance.

In a similar way, when Angel's understanding was enhanced by Mrs. Clair's examples, he gestured as if he were getting into a sleeping bag on the floor. This higher-level action combined multiple modes in its development. Initially, Angel opened the higher-level action with the request for the teacher's attention which he accomplished combining Spanish and English in the expression " $\mathrm{i}$ Miss, es asi!" (Miss, it's like this!). Simultaneously, this expression also signaled that Angel's contribution was not going to be in the spoken mode, rather there was going to be a demonstration. His demonstration of getting into a sleeping bag was both gestured and performed. Mrs. Clair acknowledged the value of Angel's act with a prolonged and accentuated "Yeees!", and then she drew the rest of the students' attention to Ángel's performance. Subsequently, Mrs. Clair used Spanish to relate the concept of sleeping bag with the word sac reinforcing Ángel's performed explanation and providing the closing bracket for the previous 
Figure 1 Illustration of Mode Density

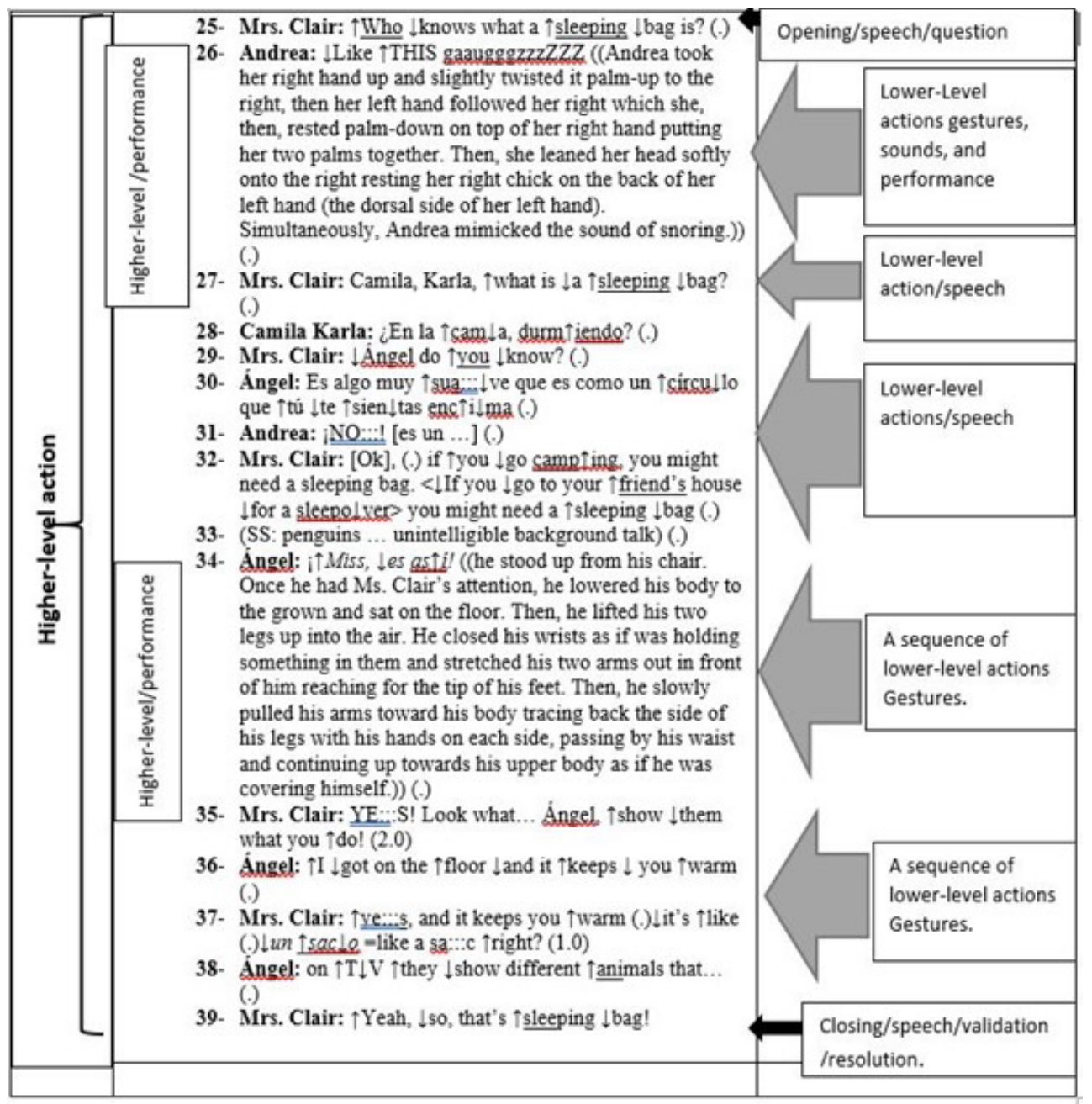

two higher-level actions. Collectively, they constructed the concept of sleeping bag. Figures 1 and 2 illustrate the complex configuration of semiotic resources and modes in the communicative action described above.

Looking at this episode from a social semiotic perspective highlights the intricate interplay in the interaction. Performance, gestures, speech, and tone of voice in Andrea and Angel's responses unveiled ways in which meaning was negotiated and achieved through cultural referents illustrating the high mode-complexity therein. Figure 2 below illustrates the mode complexity in the episode.
Figure 2 Mode Complexity of Episode 1

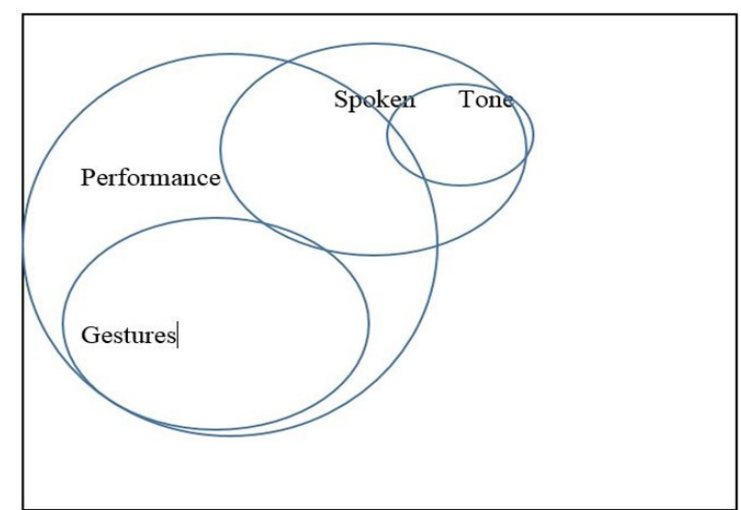




\section{Modal Complexity: Intensity in Speech}

The following episode (Table 8), The Flip-Flops Thing!, instantiates intensity in speech and exemplifies the way in which this group integrated their L1 with other semiotic resources in communication and in pursuit of their learning.

On the topic of penguins, Mrs. Clair introduced the expression webbed feet with questions about what joined the toes together. In Turn 2, Diego signaled that he had an answer by saying "the" multiple times in an attempt to hold the floor while the right word was retrieved. Unable to come up with an appropriate term, Diego appealed to the resemblance that flip-flops shared with the concept being presented and replied by saying "la chancleta thing" (the flip-flops thing), evenly combing Spanish and English.

Similar to the way in which Diego was drawing associations and moving fluidly across languages, Andrea also found a common feature shared by the penguins in the text and the mermaids in classic children's literature tales which allowed her to reveal her understanding of the concept at hand. From Turn 3, Andrea showed eagerness to tell the teacher her discovery: that mermaids had something similar joining their legs! Her contribution is entirely in Spanish, but it perfectly fits the topic and directionality of the conversation being held. Mrs. Clair, in turn, made use of this opportunity to reinforce the expression thin skin, particularly teaching Andrea the word skin in turn four providing the equivalent versions of the expression in Spanish and, subsequently, in English to draw a clear connection between the two.

Deviating from the first episode, this new act did not exhibit high-mode complexity; however, many resources were combined for communication. For starters, Mrs. Clair opened the higher-level action, the episode, with a question. Then, in Diego's intervention in the second turn of talk, there was a sequence of lower-level actions. He first announced that he had an answer and used English (semiotic system of resources) to hold the floor. He then provided an answer in both English and Spanish. There was also a higher-level action embedded within the episode. Andrea opened this higher-level action requesting attention in Turn 4; then, it was interrupted in Turn 5, and in Turn 6, Andrea resumed her higher-level action which then came to a resolution in Turn 7. For such a resolution, Mrs. Clair combined English and Spanish to acknowledge and validate Andrea's contribution. This suggests that not only were many resources used but that

Table 8 Episode 2: The Flip-Flops Thing!

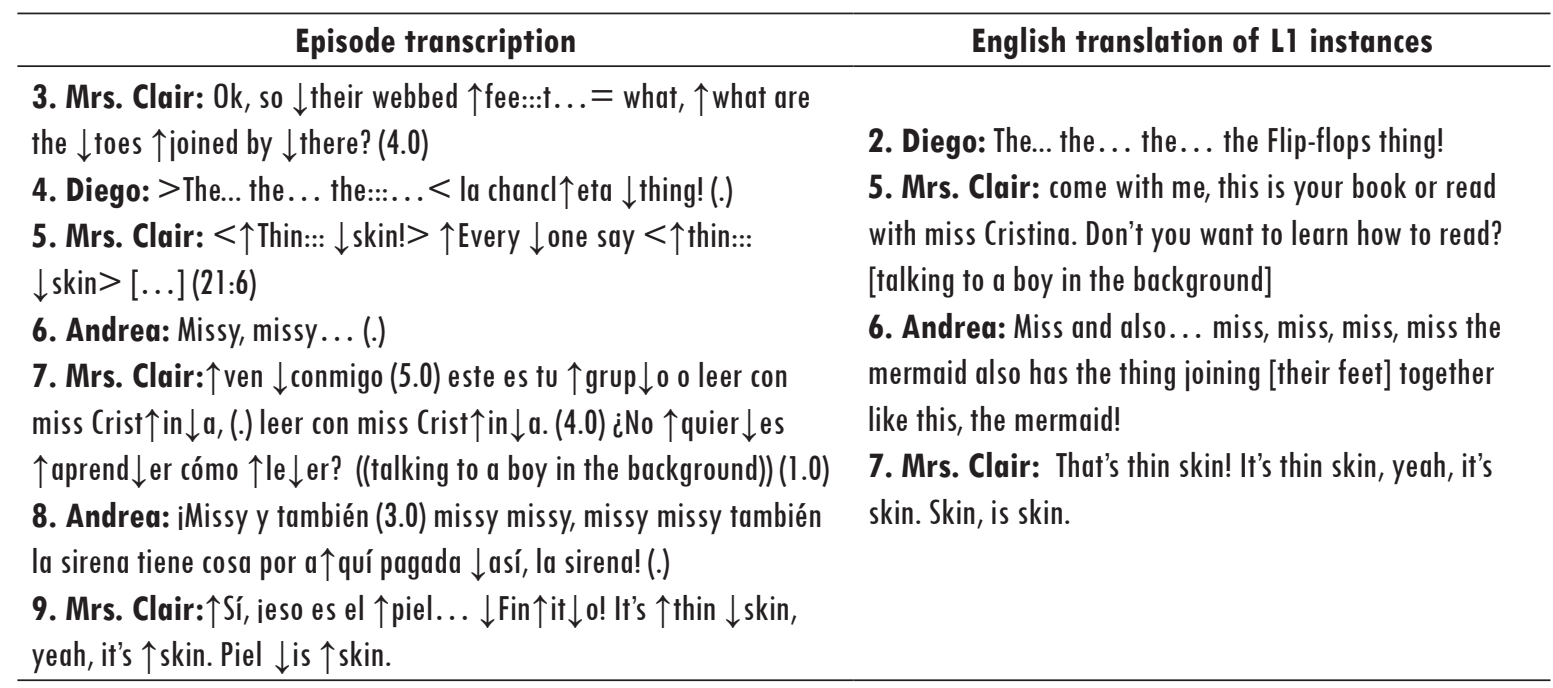


Figure 3 Mode Complexity of Episode 2

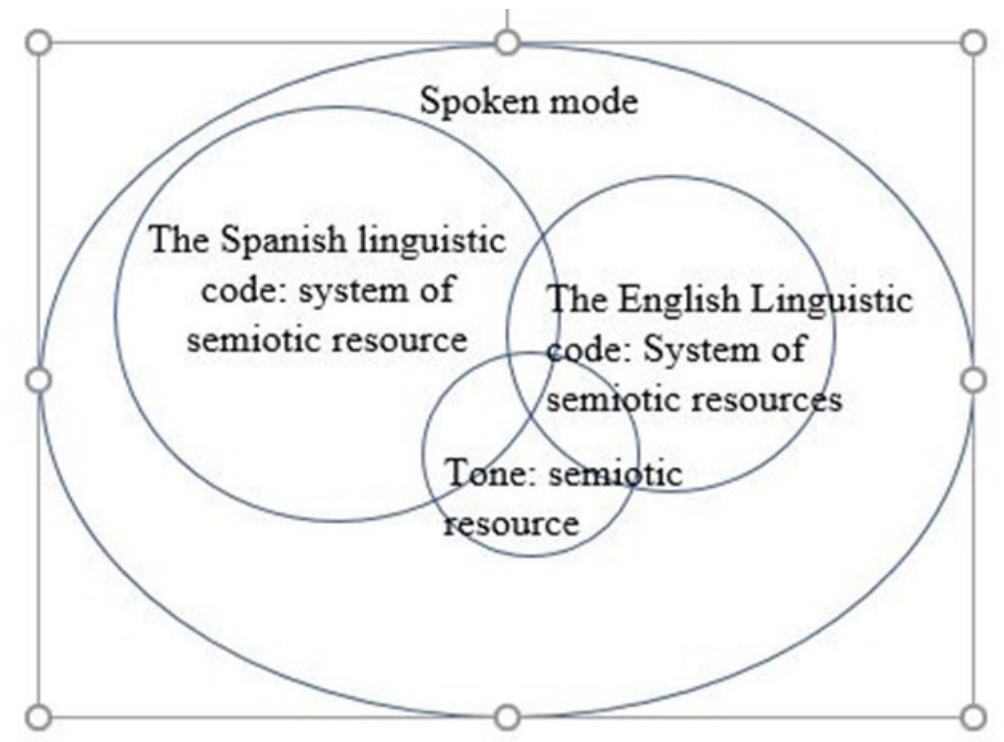

they also did not always have clear cut beginnings and endings. Often, they surfaced back up in later turns of talk in conversation. Figure 3 illustrates the episode's mode complexity.

The spoken mode exhibited the highest level of intensity with no other modes being saliently evidenced in the conversation. Within the spoken mode, however, the two linguistic codes were strategically and creatively combined by both the teacher and the students to accomplish a number of functions (e.g., hold the floor, get others' attention, express knowledge, validate, and so on). However spontaneously, this practice closely resembles translanguaging in that it makes room for the students' L1 to surface in interaction and in the interest of learning valuing their pre-exiting knowledge that students have (Ascenzi-Moreno, 2018; Cenoz \& Gorter, 2017; García-Mateus \& Palmer, 2017; Hamman, 2018; MacSwan, 2017, 2020).

\section{Modal Complexity: Combined Intensity in Speech and Performance}

Social semiotics argues that learning is an effect of communication, which is, in turn, populated with the social, cultural, and historical resources that the students are encouraged to draw on. The following episode, The Wolves Howl, illustrates such an argument (Table 9).

In Turn 11, Mrs. Clair checked for understanding of the word howl. Mia confirmed that the concept was not altogether clear when she asked for clarification in Turns 14 and 17. Then, the teacher gave examples of animals that howled, and Angel complemented the teacher's list of examples adding the wolf into it. The teacher validated Angel's contribution, but Mia was unable to draw the connection straightaway. The teacher then performed the sound wolves make (onomatopoeic sound), and Diego immediately associated it with the word lobo in Spanish for wolf in Turn 19. The teacher energetically ratified that that was what howl meant. As a product of the combination of Angel bringing in additional examples, Mrs. Clair making the sound, and her peers saying the world wolf in Spanish, Mia came to understand what howl meant and compared it to the hoot of an owl.

Mia displayed her knowledge of the word owl in both languages. Even though two distinct animals were used to draw associations to the concept at 
Table 9 Episode 3: The Wolves Howl!

\begin{tabular}{|c|c|}
\hline Episode transcription & English translation of $\mathrm{Ll}$ instances \\
\hline 1. Mrs. Clair: I L::::0ve that you want to $\uparrow$ read! (.) $\downarrow 0 k$, rea $\uparrow d y$ ? (.) & \\
\hline 2. Mrs. Clair: $\downarrow A \uparrow$ fierce (.) & \\
\hline 3. Students: $\downarrow A \uparrow$ fierce [chorus] (.) & \\
\hline 4. Mrs. Clair: $\uparrow$ wind $\downarrow$ howls (.) & \\
\hline 5. Students: $\uparrow$ wind $\downarrow$ howls [chorus] (.) & \\
\hline 6. Mrs. Clair: $>$ Do you $\uparrow$ know $<$ what $<\downarrow$ howl $\uparrow$ means? $>$ (.) & \\
\hline 7. Students: No [chorus] (.) & \\
\hline 8. Diego: Like, $\uparrow$ snow:::? (.) & \\
\hline 9. Mrs. Clair:Alondra (.) & \\
\hline 10. Alondra: like, like, like this $\uparrow$ miss? (.) & \\
\hline 11. Mrs. Clair:Do you $\uparrow$ know what $<\downarrow$ howl $\uparrow$ means? $>$ (.) & \\
\hline 12. Diego: $\downarrow$ the $\uparrow$ snow $\downarrow$ ahh $(1.0)$ blows a $\uparrow$ way? ahh... (.) & \\
\hline 13. Mrs. Clair: $\downarrow$ it's blowing ar $\uparrow$ ound a $\downarrow$ lot ... (.) & \\
\hline 14. Mrs. Clair: you know $\uparrow$ who $\downarrow$ howls? $<$ Coy $\uparrow$ ot $\downarrow$ es howl, $\uparrow$ dogs & \\
\hline [ $\downarrow$ howl]. [Mia: ¿Qué eso? overlap]. $\uparrow S o m e ~ \downarrow d$ dogs howl at the & \\
\hline $\begin{array}{l}\uparrow m o 0::: n::: \downarrow \text { or when (.) they } \uparrow \text { howl like when } \downarrow \text { the }(.) \uparrow \operatorname{sir} \downarrow \text { ens } \\
\text { go by and the police car (.) sometimes... (.) }\end{array}$ & $\begin{array}{l}\text { Mrs. Clair: you know who howls? Coyotes howl, } \\
\text { dogs howl. Some dogs howl [Mia: What's that? }\end{array}$ \\
\hline 15. Angel: the $\uparrow$ wolves? (.) & overlap] some dogs howl at the moon or when they \\
\hline 16. Mrs. Clair: the wolf, $<\uparrow$ wolves how $\downarrow \mid>$ (.) & howl like when the ... when the sirens go by and the \\
\hline 17. Mia: ¿Qué es $\uparrow$ es $\downarrow$ o? (.) & police car sometimes... \\
\hline 18. Mrs. Clair:they go $\uparrow$ like $\downarrow$ this Howllei::: ((actually howling)) (.) & Mia: What's that? \\
\hline 19. Diego: AH el $\uparrow$ lobo, el $\downarrow$ lobo ... howl (.) & \\
\hline 20. Mrs. Clair: $\uparrow$ that's how $\downarrow$ the $(.) \uparrow$ dogs $(.) \downarrow$ or the $\uparrow\lfloor o \downarrow$ bo (.) & \\
\hline 21. Diego: ilobo! (.) & Diego: ah the wolf, the wolf ... howl \\
\hline 22. Mrs. Clair: or the $<\downarrow \operatorname{coy} \uparrow$ ot $\downarrow e>$ (.) & Miss Ms. Clair: That's howl! The dogs or the wolf. \\
\hline 23. Mia: jah como los $\uparrow$ owl $\downarrow$ s! (.) & \\
\hline 24. Mrs. Clair: the $\uparrow$ wolf $\downarrow$ howls auvu $\uparrow$ right? (.) & Mia: ah like the owls! \\
\hline 25. Mia: ilgual que $\uparrow$ los (.) búh $\downarrow$ os! (.) & \\
\hline $\begin{array}{l}\text { 26. Mrs. Clair: this } \uparrow \text { here talks } \downarrow \text { about the fierce wind, the } \\
<\uparrow \text { stro:::ng } \downarrow \text { wind }>\text { when the wind is whipping } \downarrow \text { ar } \uparrow \text { ound } \downarrow \text { it } \\
\text { makes } \uparrow \text { noi } \downarrow \text { ce }(.)\end{array}$ & Mia: Exactly like the owls! \\
\hline
\end{tabular}

hand, they also shared similarities that suggested that Mia understood the concept (the sign). The students learned the word howl while simultaneously being exposed to the word wolf in English through direct association to the Spanish word lobo accompanied by the howling sounds that the teacher made. Figure 4 below illustrates the mode complexity of the episode.

\section{Discussion and Conclusions}

Spanish and English were not used in isolation from one another. On the contrary, they were integrated in broader systems of semiotic representations (resources and modes) to collectively make meaning. Such resources and modes had different levels of complexity, density, and intensity in communication. That is, they exhibited different degrees of importance in meaning-making according to the situation. Such complex and dense configuration of modes mediating these young learners' actions in communication in the episodes above had implications in three significant ways: (1) they helped establish semiotic associations across languages; (2) they validated 
Figure 4 Mode Complexity of Episode 3.

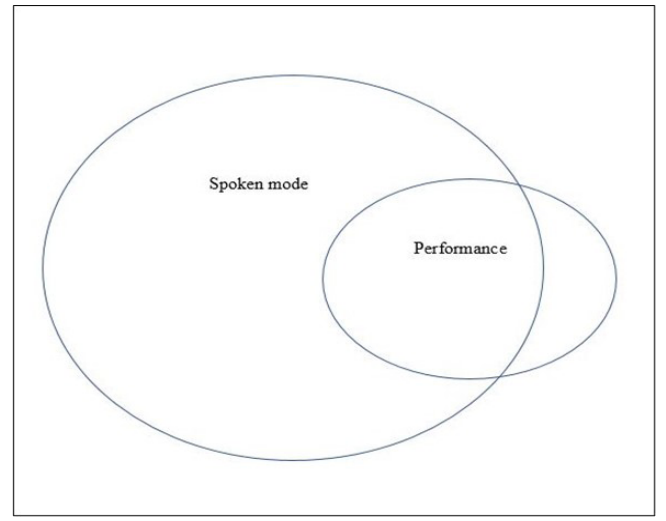

and supported the students' use of their L1 in pursuit of their learning; and (3) they established the norms of interaction that collectively constructed a safe social environment for learning.

\section{Drawing Semiotic Associations}

Across Languages for Meaning Negotiation

100

In Episode 1, both Andrea and Angel's responses used metaphoric gestures which conveyed abstract concepts (Norris, 2004). These metaphoric gestures can be thought of as signs (Kress, 2010,2011) which were charged with the maker's cultural knowledge (e.g., their language, experience, and so forth) and which were evidence of knowing. That is, they unveiled some sort of comprehension that the sign makers had about the topic and were created by the makers, Andrea and Angel, with the express purpose of relating to the social situation at hand (e.g., getting people's attention), signaling that they had knowledge about the topic (Kress, 2010, 2011).

Initially, Angel's use of Spanish in the expression Miss, es asi! in Turn 34 served to bridge the gap between Angel's knowledge and the way he chose to represent it and make it known to others. It served to announce his response and initiated a series of performed actions that were to be taken as a part of Angel's semiotic representation of the word sleeping bag (semiotic work). Similarly, in Turn 37, Mrs. Clair says "Yes, and it keeps you warm... it's like... un saco ... like a sac, right?" directly drawing a connection between the semiotic representation that Angel and his peers may have of un saco in Spanish with a new representation (the word sleeping bag in English).

Similarly, in Episode 2, while "the Flip-flops thing" in line two is not exactly the answer Mrs. Clair was looking for, it certainly does reveal a semiotic association that Diego made between the concept of webbed feet and flip-flops, exposing some sort of understanding that the learner possessed about the concept. This semiotic association is charged with Diego's sociocultural identity (García-Mateus \& Palmer, 2017) and was articulated in a phrase that evenly distributed Spanish and English-la chancleta thing.

Moreover, in Lines 6-7 in Episode 2, Andrea also found a connection between the concept introduced and her life experiences. Influenced by literature, fiction, and fantasy, Andrea made sense of the webbed feet expression by accurately associating what holds the toes in webbed feet together with what holds the mermaid's tail together.

Similarly, in Episode 3, Angel and Diego bridged their associations across languages by using Spanish and English to talk about the same animal. In Line 15 of Episode 3, Angel introduced the example of the wolves in English, and Mrs. Clair validated his intervention. A couple of turns later, this information was taken up by Diego who re-established the connection between el lobo (Spanish for wolf) and howling using the two languages and the information that his peer had previously offered (the semiotic work of the group). This served a twofold purpose: first, it allowed Diego and Mrs. Clair to confirm Diego's level of understanding of the word howl; and second, it provided Mrs. Clair with the opportunity to reinforce the equivalent word for lobo in English-wolf.

Not surprisingly, the types of associations that the students made were significantly different one from the other revealing different life experiences 
and epistemic commitments (Kress, 2010, 2011). Whereas for Angel and Diego, the howling of the wind was more closely related to the sound that wolves made, for Mia the sound of the wind resembled more closely the hoot of an owl. Mia used both Spanish and English to talk about the animal she was associating the sound to-owl in English and büho in Spanish.

In short, the students drew associations across their two languages and made use of their lived experiences to grapple with unfamiliar concepts. The possibility afforded to them of integrating the languages they spoke and the semiotic resources they had access to in communication created a positive social and emotional climate for learning. Such a climate provided the conditions for students to draw associations with previously acquired cultural and linguistic knowledge to mediate their immediate learning needs while reaffirming their sociocultural identity as emergent bilinguals (Ascenzi-Moreno, 2018; Cenoz \& Gorter, 2017; García-Mateus \& Palmer, 2017; Hamman, 2018; MacSwan, 2017, 2020).

\section{Validating the Students' Use of their L1 to Support their Learning}

A first step in creating a safe environment includes permitting students to act and interact in their own unique ways without sanctions of any shape or form (Aukerman et al., 2017; Boyd et al., 2018). Even though Mrs. Clair's intervention in Turn 30 of Episode 1 did not clearly suggest a full validation of Camila's response, it did unveil Mrs. Clair's acceptance of the forms and patterns of Camila's talk. That is, rather than demanding students to speak in English, for instance, she allowed the integration of L1 into the communication practice to occur; and in doing so, the students' identities, experiences, and knowledge were allowed to surface in interaction (Ascenzi-Moreno, 2018; Cenoz \& Gorter, 2017; García-Mateus \& Palmer, 2017; Hamman, 2018; MacSwan, 2017, 2020).
A more explicit instance of validation in Episode 1 is evidenced when Angel used Spanish to bring the teacher's attention to his response. Then, on the floor, Angel performed the act of getting inside a sleeping bag. Mrs. Claire validated his response with a prolonged and accentuated "Yeees" in Turn 13 (tone of voice). Subsequently, Mrs. Clair also validated Angel's contribution by bringing everybody's attention to what Angel was doing. Because Angel was able to create signs that unveiled his knowledge about the topic being addressed, Mrs. Clair was also able to welcome, value, and use Angel's contribution in the collective negotiation of meaning at hand and in the interest of learning (Kress, 2010, 2011).

In Episode 2, validation was evidenced when, in Turn 6, Andrea used Spanish to contribute to the co-construction of the understanding of webbed feet. In this particular instance, Mrs. Clair's intervention fulfilled a number of functions in a multiplicity of ways. First, it acknowledged that the student's response was listened to, understood, and taken up when she said "That's thin skin!" Second, Mrs. Clair's statement “That's thin skin!" also validated Andrea's knowledge about the topic under discussion as it acknowledged its accuracy. Third, by integrating Spanish in this utterance, Mrs. Clair was also validating the use of Spanish in the classroom. Finally, by stating "That's thin skin!" repetitively in the two languages, Mrs. Clair conveyed a sense of accomplishment and excitement.

Validation is also instantiated in Episode 3. Initially, Angel offered an example of an animal that howls, and Mrs. Clair validated his contribution in Turn 16 by reiterating that "the wolves howl" and later in Turn 18 by performing the onomatopoeic sound that wolves make. A second instance in which validation took place occurs when Diego, connecting the dots between what his classmate Angel and his teacher, Mrs. Clair, collectively offered on the topic, concluded that they were talking about lobos (wolves). Mrs. Clair 
validated his conclusion by saying "That's howl! The dogs or the lobo." Mrs. Clair used Spanish in this instance of validation to draw a direct and strong connection between her reiteration of what howling meant and Diego's semiotic representation (el lobo).

\section{Defining the Norms of Interaction and Constructing a Safe Social Environment for Learning}

In the episodes, Mrs. Clair's use of the students' L1 did not only fulfil the function of drawing semiotic connections across languages to enhance her students' understanding, but, as the classroom teacher, she was also establishing norms of interaction (Hymes, 1994). When Mrs. Clair did not use Spanish, she still responded coherently and consistently in English to the contributions that her students made in Spanish, validating the students' discursive practices. When Mrs. Clair did use Spanish, she often drew semiotic associations across languages to enhance her students' comprehension. Similar to the effects discussed in Leung and Uchikoshi (2012), the fact that the teacher exhibited a positive attitude toward the use of both Spanish and English and moved fluidly across the two languages sent the message that speaking Spanish was not only valued but often appropriated to enhance meaning-making in the learning process promoting such communicative practices in the classroom.

Moreover, in Episode 1, for instance, Andrea's performance of someone sleeping and snoring heavily influenced the interventions that followed. This suggests that an environment was created where, first, the expression of students' ideas was not strictly limited to the use of the spoken mode of communication in English or Spanish, but rather communication was encouraged to take on a multiplicity of modes. Second, the students and the teacher were encouraged to grapple with each other's ideas to collectively construct knowledge with the bits and pieces from everybody's multimodal participation.
Similarly, in Episode 2, la chancleta and la sirena represented building blocks that the students collectively wrestled with in the construction of the concept of webbed feet. The use of Spanish and English in these interventions also suggests that the communication of students' ideas was not limited to English but that the two languages were welcomed and that they worked together in the negotiation of meaning.

An even more explicit example of the type of social environment being created in the literacy circles of the second-grade classroom is evidenced in episode three when Angel offered an example (wolves) which initially received a simple confirmation and acknowledgement from the teacher in Turn 16 (the wolves howl). Later, however (Turn 18), the teacher took the student's example a little further and used it as the foundation to enact her performance of a wolf howling. The teacher's actions of using two languages and multiple modes of communication set the tone for a multimodal and inclusive classroom environment essential for the learning process of minoritized bilingual students (Ascenzi-Moreno, 2018; García-Mateus \& Palmer, 2017; MacSwan, 2017, 2020).

In essence, the teacher displayed remarkable ability in identifying and seizing the opportunities afforded to teaching and learning when the students' L1 was integrated in communication. Such ability benefited the students' processes providing additional semiotic resources for them to make sense of their literacy practices. Rather than being fragmented, the students' flow of communication was fueled by the use of their L1 as, to different degrees, the members of this speech community shared the two languages being spoken. Additionally, students integrated the use of Spanish and English to wrestle with each other's ideas, perspectives, and identities in the conversations about the literacy pieces they read configuring a safe social environment and creating a dialogic classroom climate (Aukerman et al., 2017; Hamman, 2018; Norris, 2004). Should 
the norms of interaction and interpretation have precluded the second graders from making the integrated use of Spanish, English, and other resources and modes discussed above, the communication would have also been truncated and learning outcomes would have been limited to the extent to which participation in communication was made available to them through the use of only a small portion of their semiotic repertoire.

The lack of understanding about the role that the students' L1 plays in enjoying (full) participation in the classroom may lead to processes of inequality, marginalization, and social injustice (Ascenzi-Moreno, 2018; Cenoz \& Gorter, 2017; García-Mateus \& Palmer, 2017; Hamman, 2018; MacSwan, 2017, 2020).

In short, understanding that learning is an effect of multimodal communication brings new considerations when striving for instructional designs that seek to create communicative environments that do not only cater to middle-class children (Flores \& García, 2017) but that also empower minoritized students to act on their own behalf and in pursuit of their learning through the use of all their semiotic resources and modes. Mrs. Clair created a social environment where Spanish and English were not treated in isolation one from the other, but rather, where they coexisted in harmony with each other and with other socio-cultural capital that the students had supporting the teaching and learning processes therein. As such, this poses pedagogical implications for the creation of social climates for learning that do not only respect the students' sociocultural background but also value it and take advantage of it to foster their intellectual development, cognitive flexibility, and bilingual identities (Ascenzi-Moreno, 2018; Cenoz \& Gorter, 2017; García-Mateus \& Palmer, 2017; Graf Estes \& Hay, 2015; Hamman, 2018; MacSwan, 2017, 2020; Poepsel \& Weiss, 2016). Finally, it also poses research implications for bilingual communication and learning presenting a comprehensive approach to researching their reciprocities in the quest for fair, inclusive, respectful, and empowering bilingual pedagogies.

\section{References}

Ascenzi-Moreno, L. (2018). Translanguaging and responsive assessment adaptations: Emergent bilingual readers through the lens of possibility. Language Arts, 95, 355-369.

Aukerman, M., Moore Johnson, E., \& Chambers Schuldt, L. (2017). Reciprocity of student and teacher discourse practices in monologically and dialogically organized text discussion. Journal of Language \& Literacy Education, 13(2), 1-52

Ben-Zeev, S. (1977). Influence of bilingualism on cognitive strategy and cognitive development. Child Development, 48, 1009-1018. https://doi. org/10.2307/1128353

Boyd, M. P., Jamark, C. J., \& Edmiston, B. (2018). Building bridges: Coauthoring a class handshake, building a classroom community. Pedagogies: An International Journal, 13(4), 330-352. https://doi.org/10.1080/ 1554480X.2018.1437731

Castles, S., De Haas, H., \& Miller, M. J. (2013). The age of migration: International population movements in the modern world. Macmillan International Higher Education.

Cenoz, J., \& Gorter, D. (2017). Minority languages and sustainable translanguaging: Threat or opportunity? Journal of Multilingual and Multicultural Development, 38(10), 901-912. https://doi.org/10 $.1080 / 01434632.2017 .1284855$

Collins, B. B. (2014). Dual language development of Latino children: Effect of instructional program type and the home and school language environment. Early Childhood Research Quarterly, 29(3), 389-397. https://doi.org/10.1016/j.ecresq.2014.04.009

Fairclough, N. (2011). Semiotic aspects of social transformation and learning. In R. Rogers (Ed.), An introduction to critical discourse analysis in education (pp. 147-155). Routledge.

Flores, S. (2010). State dream acts: The effect of in-state resident tuition policies and undocumented Latino/a students. Review of Higher Education, 33, 239-283. https://doi.org/10.1353/rhe.0.0134

Flores, N., \& García, O. (2017). A critical review of bilingual education in the United States: From basements and pride to boutiques and profit. Annual 
Review of Applied Linguistics, 37, 14-29. https:// doi.org/10.1017/S0267190517000162

Franks, A., \& Jewitt, C. (2001). The meaning of action in learning and teaching. British Educational Research Journal, 27(2), 201-218. https://doi. org/10.1080/01411920120037144

García, H., \& Nava Gómez, G. N. (2012). The impact of regional differences on elementary school teachers' attitudes towards their students' use of code switching in a south Texas school district. Profile: Issues in Teachers' Professional Development, 14(1), 67-78.

García-Mateus, S., \& Palmer, D. (2017). Translanguaging pedagogies for positive identities in two-way dual language bilingual education. Journal of Language, Identity \& Education, 16(4), 245-255. https://doi. org/10.1080/15348458.2017.1329016

Graf Estes, K., \& Hay, J. F. (2015). Flexibility in bilingual infants' word learning. Child Development, 86(5), 1371-1385. https://doi.org/10.1111/cdev.12392

Goldenberg, C., \& Coleman, R. (2010). Promoting academic achievement among English learners: A guide to the research. Corwin Press.

Goldin-Meadow, S. (2000). Beyond words: The importance of gesture to researchers and learners. Child development, 71(1), 231-239. https://doi. org/10.1111/1467-8624.00138

Hamman, L. (2018). Translanguaging and positioning in two-way dual language classrooms: A case for criticality. Language and Education, 32(1), 21-42. https://doi.org/10.1080/09500782.2017.1384006

Hymes, D. (1994). Toward ethnographies of communication. In J. Maybin (Ed.), Language and literacy in social practice: $A$ reader (pp. 11-22). Multilingual Matters, Ltd.

Jaffe, A. (2007). Codeswitching and stance: Issues in interpretation. Journal of Language, Identity, and Education, 6(1), 53-77.

Jefferson, G. (2004). Glossary of transcript symbols with an introduction. In G. H. Lerner (Ed.), Conversation Analysis: Studies from the First Generation (pp. 1331). John Benjamins. https://doi.org/10.1075/ pbns.125.02jef
Kress, G. (2010). Multimodality: A social semiotic approach to contemporary communication. Routledge.

Kress, G. (2011). Discourse analysis and education: A multimodal social semiotic approach. In R. Rogers (Ed.), An introduction to critical discourse analysis in education (pp. 205-226). Routledge.

Leung, G., \& Uchikoshi, Y. (2012). Relationships among language ideologies, family language policies, and children's language achievement: A look at Cantonese-English bilinguals in the U.S. Bilingual Research Journal, 35(3), 294-313. https://doi.org/10.1080/ 15235882.2012 .731588

Macswan, J. (2013) Codeswitching and grammatical theory. In T. Bhatia \& W. Ritchie (Eds.), The handbook of bilingualism and multilingualism (pp. 321-350). Wiley-Blackwell. https://doi. org/10.1002/9781118332382.ch13

MacSwan, J. (2017). A multilingual perspective on translanguaging. American Educational Research Journal, 54(1), 167-201.

MacSwan, J. (2020). Translanguaging, language ontology, and civil rights. World Englishes, 39(2), 321-333.

Norris, S. (2004). Analyzing multimodal interaction: A methodological framework. Routledge. https://doi. org/10.4324/9780203379493

Norris, S. (2014). The impact of literacy-based schooling on learning a creative practice: Modal configurations, practices and discourses. Multimodal Communication, 3(2), 181-195. https://doi. org/10.1515/mc-2014-0011

Poepsel, T., \& Weiss, D. J. (2016). The influence of bilingualism on statistical word learning. Cognition, 152, 9-19. https://doi.org/10.1016/j. cognition.2016.03.001

Rodríguez, M. M. (2015). Families and educators supporting bilingualism in early childhood. School Community Journal, 25(2), 177-194.

Roth, W. M. (2001). Gestures: Their role in teaching and learning. Review of Educational Research, 71(3), 365-392. https://doi. org/10.3102/00346543071003365

How to cite this article: Escobar-Alméciga, W. Y., \& Brutt-Griffler, J. (2022). Multimodal communication in an early childhood bilingual education setting: A social semiotic interactional analysis. Íkala, Revista de Lenguaje y Cultura, 27(1), 84-104. https://doi.org/10.17533/udea.ikala.v27n1a05 